Samuel O. Ebimgbo, Chiemezie S. Atama,

Chinyere E. Onalu*, Inyomoma A. Obasi-IgWe

\& GABRIEL U. AGHEDO

\title{
PREDICTORS OF LONELINESS AMONG OLDER ADULTS IN SOUTH-EASTERN NIGERIA Implications for Social Workers**
}

(Received: 1 March 2020; accepted: 30 November 2020)

Old-age loneliness is a crucial public health issue with mortality consequences as well as other negative health conditions and lifestyles including depression, substance abuse, sedentary lifestyles, and suicide ideation. This study investigated the predictors of loneliness among older adults in Nigeria's southeast in order to articulate some interventions that will plummet the issue. A structured questionnaire $(\mathrm{N}=516)$, in-depth interviews $(\mathrm{N}=8)$, and focus group discussion $(\mathrm{N}=16)$ were used to collect data from respondents aged 60 years or older. The quantitative data sets were subjected to chi-square and binary regression analysis, while a thematic analysis was adopted for the qualitative data. The study's findings show that some demographic factors such as the number of children $(\mathrm{p}<.002)$, health status $(\mathrm{p}<.023)$, and social support $(\mathrm{p}<.014)$, among others, were statistically significant in predicting loneliness among older adults. The study, therefore, recommends the consideration of community-based services to enable elderly adults to buffer the experience of loneliness. Social workers should also influence the various organs responsible for social policies to formulate and promote policies that address the well-being of older adults.

Keywords: loneliness; older adults; social policy; social workers; southeast Nigeria

\section{Introduction}

Population ageing remains a demographic issue that is prevalent in both developed and developing countries of the world (BÉLANGER et al. 2016). In 2017, estimates

\footnotetext{
Corresponding author: Chinyere E. Onalu (M.Sc), Department of Social Work, Faculty of the Social Sciences, University of Nigeria, Nsukka, 410001; chinyere.onalu@unn.edu.ng.

** Ethical considerations: Ethical issues (including plagiarism, informed consent, misconduct, data fabrication and/or falsification, double publication and/or submission, redundancy, etc.) have been completely observed by the authors.

Conflict of interest: The authors declare that there is no conflict of interest.
} 
show that the world's population of people in the ages of 60 and up stood at 962 million; this number is projected to increase to 2.1 billion by the year 2050 (United Nations Department of Economic and Social Affairs, Population Division [UN DESA] 2017). Similar to developing countries like Nigeria, the ageing population is gradually gaining currency. According to the report of the Population Reference Bureau (2020), Nigeria holds the highest number of people who are 60 years and above in Africa. The report of the UN DESA (2019) shows that the population of Nigerians in this age category is estimated to increase from 9.1 million in 2019 to 11.5 million in 2025 , and to 25.5 million in 2050 . With this, the population of Nigerian older adults may likely outgrow the total population of some African countries (such as Ghana and Senegal) in the next few years (TOGONU-BICKERSTETH \& AKINYEMI 2014). This increase in the population of elderly adults in Nigeria is associated to a great extent with numerous challenges including old-age loneliness because the country lacks well-designed policies that address the well-being of this sub-population.

Old-age loneliness has been documented as an issue of concern many countries are facing across the globe (DAHLBERG \& MCKEE 2014; TAUBE et al. 2014). About $12 \%$ to $46 \%$ of older adults across the globe have reported the experience of loneliness (DAhlBerg \& MCKee 2014; Holwerda et al. 2014). Consequently, old-age loneliness has been dubbed a public health problem (Department of Health 2012). As a concept, loneliness lacks a unified acceptable definition, however, thereby generating discrepancies in opinions among scholars (OJEMBE \& KALU 2019). For instance, loneliness is described as being or staying alone (VICTOR et al. 2000); also, loneliness is seen as a state of feeling lonely (FOKKEMA \& KNIPSCHEER 2007). However, despite the variations in conceptualizing loneliness, there is seemingly congruity regarding its impact on individuals, especially older adults (OJEMBE \& KALU 2019). Loneliness affects the mental and physical health of the elderly (DAHLBERG et al. 2015; DiNAPOLI et al. 2014). It is also a crucial risk factor for developing cardiovascular diseases such as coronary heart disease and stroke (VALTORTA et al. 2016), elevated blood pressure (SHANKAR et al. 2011), and responsible for mortality (LuO 2012). Old-age loneliness also associates with malnutrition, hospital admissions and readmissions, and substance abuse (CACIOPPO \& HAWKLEY 2009).

Studies have shown that old-age loneliness is attributed to many factors. For instance, RAHMAN and colleagues (2019) found that gender, marital status, living status, depression, concern about falling, and hearing-visual impairment were found to have an influence on loneliness among Bangladesh's older adults. Also, VALTORTA and HANRATTY (2012) found that age, social environment, driving status, place of residence, and physical or mental health are associated with loneliness. OJEMBE and KALU (2018) equally found that disability, living alone, age, weak family ties, bereavement, poor social networks, and retirement causes old-age loneliness. In China, older adults of 75 years and above, who have a poor education status, are unmarried and living alone, have fair to a poor family and non-family relationships and chronic medical conditions (Zhong et al. 2018), or are widows (CHEN \& FeELey 2014; Chen et al. 
2014a; CHEN et al. 2014b; GIERVELD et al. 2012) were found to experience more loneliness. Also, in Turkey, ARSLANTAŞ and colleagues (2015) revealed that the presence of diseases and physical handicaps, frequent intake of medication, and lack of hobbies, increased loneliness. Other factors include social support (QUEEN et al. 2014), spouse loss, decreasing functional ability, reduced social relations, and hospitalization (NiedZWiedz et al. 2016; Rico-Uribe et al. 2016; SQuires 2015; VALTORTA \& HANRATTY 2012). Also, family structure, including living arrangements, not having children, or having a smaller number of children were found to influence older adults' experiences of loneliness (BEUTEL et al. 2017; GRUNDY \& READ 2012; KORINEK 2013; VAKILI et al. 2017). Older adults who are economically disadvantaged have been found to be lonelier than older adults who are economically advantaged (BosmA et al. 2015; PINQUART \& SÖRENSEN 2001).

In Nigeria, we reported studies that have investigated old-age loneliness using either qualitative (OJEMBE \& KALU 2018; OJEMBE \& KALU 2019) or quantitative approaches (IGBOKWE et al. 2020; OJAGBEMI \& GuREJe 2019). However, a mixedmethod approach adopted by the current study as well as the implication for social workers justifies its importance. The social convoy model was used to structure the study's framework (SHERMAN et al. 2015). Individuals go through life embedded in a personal network of individuals whom they give and from whom they receive social supports. The convoy includes a protective, dynamic network of close social ties that is responsible for the provision of personal, familial, cultural, and even professional supports and linkages for an older adult. In Nigeria, old-age loneliness is occasioned by the increasing urbanization of young family members and modifications in the traditional family system. In the 1970s and 1980s, the Nigerian elderly could boast of having large networks of people including spouses, siblings, in-laws, adult children, and grandchildren, among others, to interact and relate with (OJEMBE $\&$ KALU 2018). Communal living was the order in those days and it permitted the coexistence of older adults with other family and community members, thus constant interaction and communication were assured (OLADEJI 2011). With this type of family set-up in times past and the ample interactive relationships among the elderly and their family members, the experiences of loneliness were barely detected. However, older adults may still experience loneliness despite hitherto living together with their family members due to more working wives and their children's education (OKOYE et al. 2017), as well as excessive contact with social media (OJEMBE \& KALU 2019).

In lieu of the above, the need for social work professionals becomes imperative. Social workers engage people and the social structures to address life challenges and enhance wellbeing (International Association of School of Social Work [IASSW] \& International Federation of Social Work [IFSW] 2014). For those practicing social work, the implications of loneliness are particularly prevalent in the area of adult safeguarding, where practitioners may work with vulnerable adults who are selfneglecting, or who are victims of abuse as a result of lack of social networks (COOK 2017). Thus, social workers improvise preventative measures by identifying ways to engage people, build a network of relationships providing for social support, which 
to a great extent will buffer old-age loneliness. They equally provide counselling to older adults whom loneliness affects. They focus on the strengths of older adults to promote resilience in times of loneliness. This they do by building on the resilience that the elderly have developed from coping with previous adversities, and they strive to place self-determination as the central value (The Irish Association of Social Workers' [IASW] Special Interest Group on Ageing [SIGA] 2011).

\section{Materials and methods}

\subsection{Study area}

The study was conducted in Nnewi, south-eastern Nigeria. Nnewi is made up of four communities (Otolo, Uruagụ, Umudim, and Nnewichi) with an estimated population of 9,186 people $(4,805$ males and 4,381 females) aged 60 years and older (National Population Commission [NPC] 2010). Nnewi is home to many major indigenous manufacturing industries and other socio-economic activities. Thus, people from different cultural backgrounds reside in the town in order to work, be schooled, engage in trade, and pursue many other activities. Undoubtedly, these activities occupy the young family members daily involving little or no interactions with older adults; this can largely increase the likelihood of loneliness.

\subsection{Study sample and sampling}

Through accidental sampling, 516 respondents were selected for a quantitative study while 24 participants were selected for qualitative study through snowballing. We purposively selected all of the four communities for fair representation and selected six villages from each of the communities; hence, in all, 24 villages were selected out of a totality of 43 . From the six selected villages in each of the three communities (Otolo, Uruagu, and Umudim), we selected 22 older adults because these communities are more populated than Nnewichi, where only 20 respondents were chosen in each of the six selected villages.

Furthermore, eight respondents (four males and four females) were selected for an in-depth interview (IDI) through snowball sampling. Four respondents (two males and two females) were selected from two villages (Otolo and Uruagụ), but were not included in the questionnaire. In the same vein, two focus group discussions (FGDs) were conducted with older adults in the remaining two villages (Umudim and Nnewichi). The FGD was made up of one all-male group and one all-female group comprising of eight participants in each group.

\subsection{Data types and source}

For a high level of precision, thoroughness, and comprehensive insight, a questionnaire, IDI schedule, and FGD guide were used for data collection. We administered 
132 questionnaires in Otolo, and administered the same number in Uruagu and Umudim; however, only 120 questionnaires were administered in Nnewichi. With the help of five trained research assistants who came from the area, the questionnaires were administered in the homes of the older adults. The respondents gave their consent before answering the questions and assurances of confidentiality were given to them. The questionnaire was divided into two parts; the first part investigated the demographic characteristics (sex, age, marital status, educational status, occupation, and number of children) while the second part of the questionnaire focused on the experience of loneliness. We adopted the eight-item short measure of the University of California, Los Angeles Loneliness Scale (ULS-8) (HAYs \& DimatTeo 1987) to measure the level of perceived loneliness. The scale was derived from the revised version of the 20-item UCLA (RUSSELL et al. 1980). The choice of adopting the ULS8 was informed by its high level of validity and reliability (RUSSELL et al. 1980; Wu $\&$ YAO 2008). The scale, which consists of eight items, allowed the study respondents to rate the degree of loneliness on a four-point Likert scale: (1) Never, (2) Rarely, (3) Sometimes, and (4) Always. The score for the scale ranged from 15 to 60 . Higher total scores were perceived as higher levels of loneliness experienced by older adults.

For the qualitative study, the lead researcher moderated the interview and discussion sessions while one of the other researchers served as a recorder and another as note-taker. The IDI schedule and FGD guide contained unstructured questions to enable the stimulation of further queries, which were not included in the interview but stood within the study's scope (see Table 1). All the participants were informed and were given an appointment before the exercise to avoid taking them unawares. The discussion sessions lasted for 45 minutes per session while IDIs lasted for about 35 minutes. The discussions for older adults were held in village halls while the IDI with older adults (males and females) were carried out in their various homes. Aside from ascertaining the participants' demographic information, the interview schedule and discussion guide addressed issues related to their experience of loneliness as well as the perceived factors of loneliness among the elderly, such as living arrangements, availability of social support, health status, education and income level, number of children, etc.

Table 1

Focus group discussions guide and in-depth interview schedule

\begin{tabular}{lc}
\hline & Key questions \\
\hline 1 & Describe the experience of loneliness among older adults. \\
2 & What are the causative factors of loneliness among older adults? \\
3 & What are the impacts of loneliness on older adults? \\
\hline
\end{tabular}




\subsection{Data analysis}

The data from the questionnaire were coded, computer-processed, and analysed using version 20 of the Statistical Package for the Social Sciences (SPSS). The independent variables (sex, age, marital status, educational status, etc.) were subjected to a chisquare $\left(\chi^{2}\right)$ test with experience of loneliness as the dependent variable at a $<0.05$ level of significance. Also, the relationship between sex, age, marital status, educational status, number of children, income level, living arrangements, health status and experience of loneliness were analysed using binary logistic regression at a $<0.05$ level of significance. Thematic analysis was adopted for the qualitative study; phrases with contextual connotations were pulled as illustrative quotes.

\subsection{Results presentation and discussion}

\subsubsection{Demographic characteristics of the respondents}

The analysis shows that there was an almost equal number of male $50.2 \%$ and female $49.8 \%$ of respondents as shown in Table 2. The greater proportion of them stood at less than 70 years while the majority of the respondents, $63.8 \%$, were married. Also, $95.5 \%$, being the majority, have children while $50.7 \%$ had more than six children.

Table 2

Demographic characteristics of the respondents

\begin{tabular}{|c|c|c|c|c|}
\hline \multirow{2}{*}{ Demographic data } & \multicolumn{2}{|c|}{ Frequency } & \multicolumn{2}{|c|}{ Percentage (\%) } \\
\hline & Quantitative $(N=516)$ & Qualitative $(N=24)$ & Quantitative & Qualitative \\
\hline \multicolumn{5}{|l|}{$\operatorname{Sex}$} \\
\hline Male & 259 & 12 & 50.2 & 50 \\
\hline Female & 257 & 12 & 49.8 & 50 \\
\hline \multicolumn{5}{|l|}{ Age } \\
\hline$<70$ years & 271 & 8 & 52.5 & 33.3 \\
\hline $71-80$ years & 146 & 11 & 28.3 & 45.8 \\
\hline$>81$ years & 99 & 5 & 19.2 & 20.8 \\
\hline \multicolumn{5}{|l|}{ Marital status } \\
\hline Married & 329 & 16 & 63.8 & 66.7 \\
\hline Widowed & 118 & 8 & 22.9 & 33.3 \\
\hline Separated & 22 & 0 & 4.3 & 0 \\
\hline Divorced & 17 & 0 & 3.3 & 0 \\
\hline Single & 30 & 0 & 5.8 & 0 \\
\hline
\end{tabular}




\begin{tabular}{|c|c|c|c|c|}
\hline \multirow{2}{*}{ Demographic data } & \multicolumn{2}{|c|}{ Frequency } & \multicolumn{2}{|c|}{ Percentage (\%) } \\
\hline & Quantitative $(N=516)$ & Qualitative $(N=24)$ & Quantitative & Qualitative \\
\hline \multicolumn{5}{|l|}{ Occupation } \\
\hline None & 55 & 1 & 10.7 & 4.2 \\
\hline Farmer & 121 & 2 & 23.4 & 8.3 \\
\hline Formerly employed & 81 & 3 & 15.7 & 12.5 \\
\hline Trader & 190 & 16 & 36.8 & 66.7 \\
\hline Artisan & 69 & 2 & 13.4 & 8.3 \\
\hline \multicolumn{5}{|l|}{ Education } \\
\hline None & 139 & 9 & 26.9 & 37.5 \\
\hline Primary & 110 & 11 & 21.3 & 45.8 \\
\hline Secondary & 137 & 2 & 26.6 & 8.3 \\
\hline Tertiary & 130 & 2 & 25.2 & 8.3 \\
\hline \multicolumn{5}{|l|}{ Number of children } \\
\hline None & 23 & 0 & 4.5 & 0 \\
\hline$<5$ children & 243 & 15 & 47.1 & 62.5 \\
\hline$>6$ children & 250 & 9 & 48.4 & 37.5 \\
\hline
\end{tabular}

The demographic characteristics in the qualitative study show equal percentages in gender while the majority (66.7\%) were between the ages of 60 to 75 years. Also, the majority $(66.7 \%)$ were traders while $45.8 \%$ completed first school education.

\subsubsection{Factors of loneliness among older adults}

This section explains the relationship between some selected factors and the experience of loneliness as presented in Table 3. Marital status, income level, educational level, number of children, living arrangements, social support, and state of health show a significant relationship with old-age loneliness. About $69.3 \%$ of the respondents who are married said they have not experienced loneliness. Also, the respondents $(58.3 \%)$ with a high income reported less loneliness. 
Table 3

Factors associated with the experience of old-age loneliness

\begin{tabular}{|c|c|c|c|c|}
\hline Variables & $\begin{array}{l}\text { Had Experienced } \\
\text { Freq. (\%) }\end{array}$ & $\begin{array}{c}\text { Never experienced } \\
\text { Freq. }(\%)\end{array}$ & Total & $\chi^{2}$ \\
\hline $\operatorname{Sex}$ & & & & 0.327 \\
\hline Male & $90(47.4)$ & $169(51.8)$ & $259(50.2)$ & \\
\hline Female & $100(52.6)$ & $157(48.8)$ & $257(49.8)$ & \\
\hline Total & $190(100)$ & $326(100)$ & $516(100)$ & \\
\hline Marital status & & & & $0.000 *$ \\
\hline Single/separated/widowed & $89(46.8)$ & $100(30.7)$ & $189(36.6)$ & \\
\hline Married & $101(53.2)$ & $226(69.3)$ & $327(63.4)$ & \\
\hline Total & $190(100)$ & $326(100)$ & $516(100)$ & \\
\hline Income level & & & & $0.016^{*}$ \\
\hline Lower income & $165(52.6)$ & $256(41.7)$ & $421(81.6)$ & \\
\hline Higher income & $25(47.4)$ & $70(58.3)$ & $95(18.4)$ & \\
\hline Total & $190(100)$ & $326(100)$ & $516(100)$ & \\
\hline Educational status & & & & $0.008^{*}$ \\
\hline Lower education & $155(81.6)$ & $94(28.8)$ & $249(75.0)$ & \\
\hline Higher education & $35(18.4)$ & $232(71.2)$ & $267(25.0)$ & \\
\hline Total & $190(100)$ & $326(100)$ & $516(100)$ & \\
\hline Having children & & & & $0.015^{*}$ \\
\hline Have children & $176(35.9)$ & $317(60.9)$ & $493(95.5)$ & \\
\hline Do not have children & $14(64.1)$ & $9(39.1)$ & $23(4.5)$ & \\
\hline Total & $190(100)$ & $326(100)$ & $493(100)$ & \\
\hline Number of children & & & & $0.000^{*}$ \\
\hline Below 5 children & $79(41.5)$ & $87(25.9)$ & $166(32.2)$ & \\
\hline More than 5 children & $111(58.5)$ & $239(74.1)$ & $350(67.8)$ & \\
\hline Total & $190(100)$ & $326(100)$ & $516(100)$ & \\
\hline Living Arrangement & & & & $0.030^{*}$ \\
\hline Living with family members & $35(39.5)$ & $243(71.1)$ & $118(22.9)$ & \\
\hline Not living with family members & $155(60.5)$ & $83(28.9)$ & $398(77.1)$ & \\
\hline Total & $190(100)$ & $326(100)$ & $516(100)$ & \\
\hline Social support & & & & $0.003^{*}$ \\
\hline Adequate support & $89(31.0)$ & 201(55.4) & $290(56.2)$ & \\
\hline Inadequate support & $101(69.0)$ & $125(44.6)$ & $226(43.8)$ & \\
\hline Total & $190(100)$ & $326(100)$ & $516(100)$ & \\
\hline State of health & & & & $0.000 *$ \\
\hline Health challenge & $141(57.6)$ & $36(32.9)$ & $431(100)$ & \\
\hline No health challenge & $49(42.4)$ & $290(67.1)$ & $85(100)$ & \\
\hline Total & $190(100)$ & $326(100)$ & $516(100)$ & \\
\hline
\end{tabular}

${ }^{*}$ Association is significant at $p<0.05$. 
Some of the findings were validated by the responses from our qualitative study. For instance, a male respondent in the IDI conducted in Otolo reflected on the significance of income level on old-age loneliness:

'Someone's income determines the extent of the relationship with other people. Some elite families because of their status in society have all the facilities that are required to make one healthy and happy. Also, people always visit them to interact and socialize with them. I recall when we were living at Abakaliki, some of the rich men with large compounds constructed some recreational facilities which attract many people to their homes.'

Also, this following quote reflects the opinion of a female respondent in the IDI conducted in Uruagụ:

'The rich always show off and like the saying in my place, "big man talk to big man". They regularly meet together to enjoy and also assist one another. If someone like me goes to a rich man's house, he will say "where does this one come from?" But if a fellow rich person visits, once they see each other and have a need which only money can solve they start solving it immediately.

The findings also showed a significant association $(\mathrm{P}<0.008)$ between educational level and loneliness. Corroborating the information from our qualitative study, a female participant in the FGD conducted in Umudim reflected, 'Someone's education can help to refrain from loneliness because educated people have many connections and contacts, numerous friends either from them or from their children who often visit them'. Also, a male respondent in the IDI conducted in Otolo said, 'Education gives opportunity to have many friends who can still relate with each other despite being kept afar because of space and time.'

The findings further revealed a significant relationship $(\mathrm{P}<0.000)$ between the number of children and the experience of loneliness. However, this finding contradicted the finding from our qualitative data which indicated that the number of children has no relationship with loneliness. For instance, a participant in the FGD conducted with male older adults at Nnewichi reflected on this as follows:

'The number of children is not necessary for keeping company with older adults. I am saying this because someone may have just one child and he or she feels happy more than someone with numerous children because that only child will always comfort, care and support the parents whereas many children may end up instigating pains in the life of their older parents. The most important thing is how the children are trained.'

\subsubsection{Predictors of old-age loneliness}

The following constituted the reference categories in the analysis as shown in Table 4: being single, with a lower educational status, having fewer than five children, without a monthly stipend, having inadequate social support or family members' awareness, and possessing health challenges. With a Beta coefficient of 0.494. 
Table 4

Binary logistic regression analysis predicting old-age loneliness

\begin{tabular}{cccc}
\hline Independent variables & Beta Coefficient & Level of Significance & Odds Ratio \\
\hline Marital status & .494 & $.019^{*}$ & 1.638 \\
Level of education & .724 & $.016^{*}$ & 2.062 \\
Number of children & .629 & $.002^{*}$ & 1.879 \\
Monthly stipend & -.155 & .452 & .857 \\
Living arrangements & -.574 & $.052^{*}$ & .564 \\
Social support & -.541 & $.014^{*}$ & .582 \\
Health status & -.645 & $.023^{*}$ & .525 \\
\hline
\end{tabular}

${ }^{*}$ Significant at $p<0.05$.

$0.724,0.629,-0.574,-0.541$ and -0.645 respectively: marital status, level of education, number of children, living arrangement, social support and state of health recorded a positive relationship as predictors of the experience of old-age loneliness. The odds ratios for the independent variables are given as 1.638, 2.062, 1.879, .564, .582 and .525 . All the variables were statistically significant $(\mathrm{p}<0.05)$. However, variables such as income level did not affect the people's feeling of loneliness.

\section{Discussion}

This study investigated the predictors of loneliness among older adults and the social work implications in south-eastern Nigeria. Marital status was found to stand as one of the factors that influence the experience of loneliness. Married older adults were $69.3 \%$ less likely to have experienced loneliness as compared to unmarried older adults $(30.7 \%)$. Across the globe, to a great extent marriage provides spouses the opportunity for companionship and interaction which buffers loneliness. This finding corroborates the study conducted in the county of Shanghai, China, in which older adults aver that their partners support them by keeping them company and talking with them all the time (CHEN et al. 2014a; CHEN et al. 2014b). In Eastern and Western Europe, however, living with adult children may provide some level of protection against loneliness, but not to the same extent as having a partner or spousal relationship (GIERVELD et al. 2012). Similar findings have been reported in other studies (NiEdzwiEdz et al. 2016; Rico-Uribe et al. 2016; SQuires 2015). This finding strongly suggests the need for social workers who are chiefly involved in the welfare services of individuals, groups, and societies in order to influence government, institutions or organizations that provide welfare services to develop suitable welfare programmes such as community-based services. Considering providing communitybased intervention programs such as supplementary care, and day care among others for the elderly in Nigeria will buffer some of the challenges faced by older adults 
- especially unmarried older adults. Окоуе (2013) found that community-based services are crucial in helping older adults living alone in their homes, to maintain functionality and achieve successful aging. Community-based services were found to be instrumental in providing elderly adults with some social and emotional benefits that can help to lessen their feelings of loneliness, boredom and solitude, and improve their quality of life (JАCOB 2007).

The findings of this study also revealed that the number of children is another factor influencing old-age loneliness. Older adults with a larger number of children, as shown in Table 3, were $74.1 \%$ less likely to experience loneliness as compared to the older adults with a lower number of children. Among Africans, especially in the south-eastern part of Nigeria, marriage is the most acceptable way of increasing the household size through procreation. Among the south easterners, childless couples and couples with fewer children usually feel dissatisfied and uneasy with life because children are seen as a source of social protection in later life. The finding validates a study in Eastern Europe where several children and grandchildren are associated with positive assessments of one's social relationships, thereby reducing loneliness in old age (KORINEK 2013). In Yazd, Iran, loneliness is more prevalent in older adults who have a smaller number of children because these children act as a source of support to their older parents (VAKILI et al. 2017).

On the contrary, our qualitative study disagreed with the finding above, that is, that a high number of children reduces old-age loneliness. The responses from the qualitative study revealed that the number of children does not determine the feeling of old-age loneliness. Bringing up children remains crucial because a single child with adequate training will eventually grow up to fill the vacuum of many children who possess inadequate upbringing. A popular adage among Igbo south-eastern Nigerians is that 'Ample children without adequate training are equivalent to none'. Therefore, social workers should create an awareness for the need for couples to give birth to children they can train adequately instead of giving birth to many children without adequate training and thereby culminate in neglect and loneliness during old age. Also, in southeast Nigeria, despite the prevalence of migration and the gradual disintegration of the family system, older adults with a smaller number of children could still confine themselves to other family or community members and activities as a measure in overcoming old-age loneliness. Studies have shown that social and cultural activities in society - such as village meetings, marriage ceremonies, child naming or dedications, funerals, postpartum care - are a veritable means of support to older adults (EBIMGBo et al. 2019). Thus, social workers are needed to encourage older adults to participate in some of these activities in order to reduce their experience of loneliness.

Another finding of the study is that elderly adults' income level determines the extent of their loneliness. Older adults with higher levels of income are $58.3 \%$ less likely to experience loneliness than those with lower income levels. The obtained qualitative data have shown that older adults' income determines the relationships they will have with people. People will always visit wealthy families or households 
for interaction and socialization. Wealthy families will always have the wherewithal to attract people, social, political, economic or commercial activities, thereby reducing the level of loneliness among their aged members. Similar conclusions validate our finding that older adults who are economically disadvantaged are lonelier than others who are economically buoyantly advantaged (BOSMA et al. 2015; PINQUART \& SÖRENSEN 2001). A study by EBIMGBo and colleagues (2020) has revealed that the economic support for Nigerian older adults is poor and uncoordinated. Thus, through lobbying, social workers should facilitate the social security policies that will address the financial wellbeing of older adults in Nigeria. Currently, the bill that provides elderly adults the right to social protection, including income security, has passed the second reading in the Nigerian Senate (Окоуе 2020). Social workers should facilitate legislative actions to transform the bill for the benefit of Nigeria's older adults. Through advocacy, professionals should challenge the non-payment of pension benefits to retirees.

With a Beta coefficient of $0.494,0.724,0.629,-0.574,-0.541$ and -0.645 , marital status, level of education, number of children, living arrangement, social support and state of health were significant in predicting old-age loneliness. Further justifying these findings is the social convoy model (SHERMAN et al. 2015), which posits that people go through life in a personal network of significant others where both support giving and receiving are made possible. Thus, if spouses with adequate education and sound health, remain together with their children and significant others who provide support (health, financial, material etc.), old-age loneliness will be barely experienced. Similar findings were also obtained across other studies (DAHLBERG \& MCKEE 2014; DAHLBERG et al. 2015; QueEN et al. 2014). Thus, the findings suggest the need for professional social workers to embark on mass literacy through educating the populace on the importance of planning for old age. The awareness may include challenges associated with aging, of which loneliness is a part. This will help individuals possess the necessary knowledge to overcome loneliness in old age.

\section{Conclusion}

The study investigated the factors that predict loneliness among older adults in southeast Nigeria. Loneliness is recognized as a public health problem and also one of the issues of concern that many countries are facing across the globe. Old-age loneliness is responsible for a mental, physical and emotional breakdown in older adults. Loneliness in old age is also a crucial risk factor for cardiovascular disease, coronary heart disease and stroke; it leads to elevated blood pressure, heightened inflammatory and metabolic responses to stress with mortality consequences. From the finding, a majority of the respondents $(50.4 \%)$ indicated that they have experienced loneliness; whereas some factors such as marital status, income level, state of health, having children, and the number of children, were significant factors of loneliness. Also, some demographic characteristics, including marital status, level of education, social support, number of children, health status, etc., stood as predictors of loneliness among 
elderly adults in the study area. This study therefore recommends that communitybased services should be introduced in Nigeria in order to enable social workers to have a good interaction with older adults, thereby reducing loneliness in old age. Also, social work professionals in Nigeria have crucial roles to play in order to prevent future occurrences of old-age loneliness. As professionals who promote the social cohesion of people, engaging people and structures to address life challenges and enhance wellbeing, social workers should address old age loneliness through advocacy, negotiation, mediation and brokering. Some countries, such as the United Kingdom, had established the Campaign to End Loneliness in 2011 as a network of national, regional, and local organizations working together to ensure that loneliness is acted upon as a public health priority at national and local levels (Campaign to End Loneliness 2011). Similarly, the New Zealand government has committed itself to a vision of positive aging principles which promote community participation and prevent social isolation (MSD 2001). Nigerian social workers should influence national policies and public campaign programmes that will target tackling old-age loneliness as obtained in the developed countries. Finally, social workers can facilitate the review of Nigerian education policies and systems in order to include the study of older adults in school curriculums at all levels. This will ensure that the study of the elderly cuts across every educational level (primary, secondary, tertiary) so as to help educate the younger ones, family members, and care givers on the process of aging and also to acquire basic knowledge that entails care and support for older adults.

\section{References}

Arslantaș, H., F. Adana, F.A. Ergin, D. Kayar \& G. Acar (2015) 'Loneliness in Elderly People, Associated Factors and Its Correlation with Quality of Life: A Field Study from Western Turkey', Iran Journal of Public Health 44(1), 43-50, retrieved 3 May 2021 from https://ijph. tums.ac.ir/index.php/ijph/article/view/3729.

Bélanger, E., T. Ahmed, A. Vafaei, C.L. Curcio, S.P. Philips \& M.V. Zunzunegui (2016) 'Sources of Social Support Associated with Health and Quality of Life: A Cross-Sectional Study among Canadian and Latin American Older Adults', BMJ Open 6, 1-10 (http://dx.doi.org/10.1136/bmjopen-2016-011503).

Beutel, M.E., E.M. Klein, E. BrähleR, I. Reiner, C. JÜnger, M. Michal, J. Wiltink, P.S. Wild, T. MünZel, K.J. Lackner \& A.N. Tibubos (2017) 'Loneliness in the General Population: Prevalence, Determinants and Relations to Mental Health', BMC Psychiatry 17, 97 (https:// doi.org/10.1186/s12888-017-1262-x).

Bosma, H., M. Jansen, S. Schefman, K.J. Hajema \& F. Feron (2015) 'Lonely at the Bottom: A Cross-Sectional Study on Being Ill, Poor, and Lonely', Public Health 129(2), 185-87 (https://doi.org/10.1016/j.puhe.2014.11.016).

CACIOPPO, J.T. \& L.C. HAWKLEY (2009) 'Perceived Social Isolation and Cognition', Trends in Cognitive Sciences, 13(10), 447-54 (https://doi.org/10.1016/j.tics.2009.06.005).

Campaign to End Loneliness (2011) Safeguarding the Convoy: A Call to Action from the Campaign to End Loneliness, retrieved 3 May 2021 from https://www.campaigntoendloneliness. org/wp-content/uploads/Safeguarding-the-Convoy.-A-call-to-action-from-the-Campaignto-End-Loneliness.pdf. 
CHEN, Y. \& T.H. Feeley (2014) 'Social Support, Social Strain, Loneliness, and Well-Being Among Older Adults: An Analysis of the Health and Retirement Study', Journal of Social and Personal Relationships 31(2), 141-61 (https:// doi.org/10.1177/0265407513488728).

Chen, Y., A. Hicks \& A.E. While (2014a) 'Loneliness and Social Support of Older People in China: A Systematic Literature Review', Health and Social Care in the Community 22(2), 113-23 (https://doi.org/10.1111/hsc.12051).

Chen, Y., A. Hicks \& A.E. While (2014b) 'Loneliness and Social Support of Older People Living Alone in a County of Shanghai, China', Health \& Social Care in the Community 22(4), 42938 (https://doi.org/10.1111/hsc.12099).

Cook, S. (2017) 'Social Work and its Role in Tackling Loneliness', published 27 Oct 2017, retrieved 3 May 2021 from https://www.plymouth.ac.uk/news/pr-opinion/social-work-andits-role-in-tackling-loneliness.

DAhlberG, L. \& K.J. MCKeE (2014) 'Correlates of Social and Emotional Loneliness in Older People: Evidence from an English Community Study', Aging and Mental Health 18(4), 504 14 (https://doi.org/10.1080/13607863.2013.856863).

Dahlberg, L., L. Andersson, K.J. Mckee \& C. Lennartsson (2015) 'Predictors of Loneliness among Older Women and Men in Sweden: A National Longitudinal Study', Aging and Mental Health 19(5), 409-17 (https://doi.org/10.1080/13607863.2014.944091).

Department of Health (2012) The Adult Social Care Outcomes Framework 2013/14, retrieved 5 May 2021 from https://assets.publishing.service.gov.uk/government/uploads/system/uploads /attachment_data/file/141627/The-Adult-Social-Care-Outcomes-Framework-2013-14.pdf.

DinApoli, E.A., B. WU \& F. Scogin (2014) 'Social Isolation and Cognitive Function in Appalachian Older Adults', Research on Aging 36(2), 161-79 (https://doi.org/10.1177/01640 27512470704).

Ebimgbo, S.O., C.N. Obi-Keguna, N.E. Chukwu, C.E. Onalu, S.E. Abonyi \& U.O. Okoye (2019) 'Culture-Based Social Support to Older Adults in Nnewi, South-East Nigeria', African Population Studies 33(2), 4891-900 (https://doi.org/10.11564/33-2-1402).

Ebimgbo, S.O, P. Agwu, N. Chukwu \& U. Okоye (2020) 'Appraising Sufficiency of Financial Support for Older Adults in Anambra State, Nigeria', Ageing International 2020 (https:// doi.org/10.1007/s12126-020-09379-6).

FoKKeMA, T. \& K. KNIPSCHEER (2007) 'Escape Loneliness by Going Digital: A Quantitative and Qualitative Evaluation of a Dutch Experiment in Using ECT to Overcome Loneliness among Older Adults', Aging \& Mental Health 11(5), 496-504 (http://doi.org/10.1080/13607860 701366129).

Gierveld, J., P.A. DyKSTRA \& N. SchENK (2012) 'Living Arrangements, Intergenerational Support Types and Older Adult Loneliness in Eastern and Western Europe', Demographic Research 27(7), 167-200 (http://doi.org/10.4054/DemRes.2012.27.7).

Grundy, E. \& S. ReAD (2012) 'Social Contacts and Receipt of Help Among Older People in England: Are There Benefits of Having More Children?' The Journals of Gerontology: Series B 67(6), 742-54 (https://doi.org/10.1093/geronb/gbs082).

HAYs, R.D. \& M. R. DimatTEO (1987) 'A Short-Form Measure of Loneliness', Journal of Personality Assessment 51(1), 69-81 (https://doi.org/10.1207/s15327752jpa5101_6).

Holwerda, T.J., D.J.H. Deeg, A.T.F. Beekman, T.G. Van Tilburg, M.L. Stek, C. Jonker \& R.A. SchoEvers (2014) 'Feelings of Loneliness, but not Social Isolation, Predict Dementia Onset: Results from the Amsterdam Study of the Elderly (AMSTEL)', Journal of Neurology, Neurosurgery, \& Psychiatry 85(2), 135-42 (http://dx.doi.org/10.1136/jnnp-2012-302755).

Igbokwe, C.C., V.J. EJeh, O.S. Agbaje, P.I.C. Umoke, C.N. Iweama \& E.L. Ozoemena (2020) 'Prevalence of Loneliness and Association with Depressive and Anxiety Symptoms among 
Retirees in Northcentral Nigeria: A Cross-Sectional Study', BMC Geriatrics 20, 153 (https://doi.org/10.1186/s12877-020-01561-4).

International Association of School of Social Work (IASSW) \& International Federation of Social Work (IFSW) (2014) Global Definition of Social Work, retrieved 24 April 2021 from http://ifsw.org/what-is-social-work/global-definition-of-social-work.

JACOB, M.E., V.J. ABRAHAM, S. ABRAHAM \& K.S. JACOB (2007) 'Effect of Community Based Day Care on Mental Health and Quality of Life of Older in Rural South India: A Community Intervention Study', International Journal of Geriatric Psychiatry 22(5), 445-47 (https:// doi.org/10.1002/gps.1706).

KorINEK, K. (2013) 'Family Relations and the Experience of Loneliness among Older Adults in Eastern Europe' in S.A. MCDANIEL \& Z. ZIMMER, eds., Global ageing in the twenty-first century: Challenges, Opportunities and Implications (Burlington: Ashgate) 267-90.

Luo, Y., L.C. HaWkLeY, L.J. Waite \& J.T. CACIOPPo (2012) 'Loneliness, Health, and Mortality in Old Age: A National Longitudinal Study', Social Science Medicine 74(6), 907-14 (https://doi.org/10.1016/j.socscimed.2011.11.028).

Ministry of Social Development (2001) New Zealand Positive Ageing Strategy (Wellington: Ministry of Social Policy).

National Population Commission (NPC) (2010) Federal Republic of Nigeria 2006 Population and Housing Census: Priority Table Volume IV, Population Distribution by Age \& Sex (State \& Local Government Area) (Abuja: National Population Commission) retrieved 6 May 2021 from https://catalog.ihsn.org/index.php/catalog/3340/download/48521.

Niedzwiedz, C.L., E.A. Richardson, H. Tunstall, N.K. Shortt, R.J. Mitchell \& J.R. Pearce (2016) 'The Relationship Between Wealth and Loneliness Among Older People Across Europe: Is Social Participation Protective?' Preventive Medicine 91, 24-31 (https://doi.org/ 10.1016/j.ypmed.2016.07.016).

Ojagbemi, A. \& O. Gureje (2019) 'Social Relationships and the Association of Loneliness with Major Depressive Disorder in the Ibadan Study of Aging', World Social Psychiatry 2019(1), 82-88, retrieved 24 April 2021 from https://www.worldsocpsychiatry.org/text.asp?2019/ $1 / 1 / 82 / 267972$.

OJemBe, B.U. \& M.E. KALU (2018) 'Describing Reasons for Loneliness among Older People in Nigeria', Journal of Gerontological Social Work 61(6), 640-58 (https://doi.org/10.1080/ 01634372.2018.1487495).

OJembe, B.U. \& M.E. Kalu (2019) 'Television, Radio, and Telephone: Tools for Reducing Loneliness among Older Adults in Nigeria', Gerontechnology 18(1), 36-46 (https://doi.org/ 10.4017/gt.2019.18.1.004.00).

Окоуе, U. O. (2013) 'Community-Based Care for Home Bound Elderly Persons in Nigeria: A Policy Option', International Journal of Innovative Research in Science, Engineering and Technology 2(12), 7086-91, retrieved 22 Apr 2021 from http://www. ijirset.com/upload/2013/ december/4_Community.pdf.

Oкоуе, K. (2020) 'Bill to Protect Rights, Privileges of Older Persons Passes 2nd Reading at Senate', NNN News Nigeria, published 17 March 2017, retrieved 3 May 2021 from https:// nnn.com.ng/bill-to-protect-rights-privileges-of-older-persons-passes-2nd-reading-at-senate/.

Okoye, U., S.O. Ebimgbo \& J. Ene (2017) 'Social Work with Older Adults in Nigeria' in U. Okoye, N. Chukwu \& P. Agwu, eds., Social Work in Nigeria: Book of Reading (Nsukka: University of Nigeria Press) 160-171.

OladeJI, D. (2011) 'Family Care, Social Services, and Living Arrangements Factors Influencing Psychosocial Well-Being of Elderly from Selected Households in Ibadan, Nigeria', Education Research International 2011, Article ID 421898, 1-6 (https://doi.org/10.1155/2011/ 421898). 
PINQuART, M. \& S. SöRENSEN (2001) 'Influences on Loneliness in Older Adults: A Meta-Analysis', Basic and Applied Psychology 23(4), 245-66 (https://doi.org/10.1207/S15324834BASP 2304_2).

Population Reference Bureau (2020) Countries with the Oldest Population in the World, retrieved 3 May 2021 from https://www.prb.org/countries-with-the-oldest-populations/.

Queen, T.L., R.S. Stawski, L.H. Ryan \& J. SMith (2014) 'Loneliness in a Day: Activity Engagement, Time Alone, and Experienced Emotions', Psychology and Aging 29(2), 297-305 (https://doi.org/10.1037/a0036889).

Rahman, S., A. Rahman \& S. Rahman (2019) 'Prevalence and Determinants of Loneliness Among Older Adults in Bangladesh', International Journal of Emerging Trends in Social Sciences 5(2), 57-64 (https://doi.org/10.20448/2001.52.57.64).

Rico-Uribe, L.A., F.F. Caballero, B. Olaya, B. Tobiasz-Adamczyk, S. Koskinen, M. Leonardi, J.M. Haro, S. ChatterJi, J.L. Ayuso-Mateos \& M. Miret (2016) 'Loneliness, Social Networks, and Health: A Cross-Sectional Study in Three Countries', PLoS One 11(1), e0145264 (https://doi.org/10.1371/journal.pone.0145264).

Russell, D., L.A. Peplau \& C.E. Cutrona (1980) 'The Revised UCLA Loneliness Scale: Concurrent and discriminate validity evidence', Journal of Personality and Social Psychology 39(3), 472-80 (https://doi.org/10.1037//0022-3514.39.3.472).

Shankar, A., A. Mcmunn, J. Banks \& A. Steptoe (2011) 'Loneliness, Social Isolation, and Behavioral and Biological Health Indicators in Older Adults', Health Psychology 30(4), 377-85 (https://doi.org/10.1037/a0022826).

Sherman, C.W., W.H. WAN \& T.C. Antonucci (2015) 'Social Convoy Model' in S.K. Whitbourne, ed., The Encyclopedia of Adulthood and Aging 1-5 (Hoboken: Wiley) (https://doi.org/10. 1002/9781118521373.wbeaa094).

SQuires, S.E. (2015) 'To a Deeper Understanding of Loneliness amongst Older Irish Adults', Collegium Antropologicum 39(2), 289-95.

Taube, E., J. Kristensson, M. Sandberg, P. Midlöv \& U. Jakobsson (2014) 'Loneliness and Health Care Consumption among Older People', Scandinavian Journal of Caring Sciences 29(3), 435-43 (https://doi.org/10.1111/scs.12147).

The Irish Association of Social Workers' (IASW) Special Interest Group on Ageing (SIGA) (2011) The Role of the Social Worker with Older Persons, retrieved 3 May 2021 from https://www. iasw.ie/download/367/d82b4fe7-b766-4792-83d7-75eefb001b6c.pdf.

Togonu-Bickersteth, F. \& A.I. AkinYemi (2014) 'Ageing and National Development in Nigeria: Costly Assumptions and Challenges for the Future', African Population Studies 27(2), 36171 (https://doi.org/10.11564/27-2-481).

United Nations Department of Economic and Social Affairs, Population Division (2017) World Population Ageing 2017 - highlights (ST/ESA/SER.A/397) retrieved 6 May 2021 from https://www.un.org/en/development/desa/population/publications/pdf/ageing/WPA2017_ Highlights.pdf.

United Nations Department of Economic and Social Affairs, Population Division (2019) World population prospects 2019, retrieved 3 May 2021 from https://population.un.org/wpp/DataQuery/.

VAKiLI, M., M. MirZaei \& M. ModarResi (2017) 'Loneliness and its Related Factors among Elderly People in Yazd', Elderly Health Journal 3(1), 10-15, retrieved 22 April 2021 from http://ehj.ssu.ac.ir/article-1-74-en.pdf

VAltorta, N. \& B. Hanratty (2012) 'Loneliness, Isolation and the Health of Older Adults: Do we Need a New Research Agenda?' Journal of Royal Society and Medicine 105(12), 518 22 (https://doi.org/10.1258/jrsm.2012.120128). 
Valtorta, N.K., M. KanaAn, S. Gilbody, S. Ronzi \& B. HanRatTy (2016) 'Loneliness and Social Isolation as Risk Factors for Coronary Heart Disease and Stroke: Systematic Review and Meta-Analysis of Longitudinal Observational Studies', Heart 102(13), 1009-16 (http://dx. doi.org/10.1136/heartjnl-2015-308790).

Victor, C., S. ScAmbler, J. Bond \& A. Bowling (2000) 'Being Alone in Later Life: Loneliness, Social Isolation and Living Alone', Reviews in Clinical Gerontology 10(4), 407-17 (https://doi.org/10.1017/S0959259800104101).

Wu, C.-H. \& G. YAO (2008) 'Psychometric Analysis of the Short-Form UCLA Loneliness Scale (ULS-8) in Taiwanese Undergraduate Students', Personal Individual Differences 44(8), 1762-71 (https://doi.org/10.1016/j.paid.2008.02.003).

Zhong, B.L., X.J. LiU, W.C. Chen, H.F.K. ChiU \& Y. Conwell (2018) 'Loneliness in Chinese Older Adults in Primary Care: Prevalence and Correlates', Psychogeriatrics 18(5), 334-42 (https://doi.org/10.1111/psyg.12325). 